\title{
Marine Impacts and Environmental Consequences - Drilling of the Mjølnir Structure, the Barents Sea
}

\author{
by Henning Dypvik, Philippe Claeys, Alex Deutsch, Frank T. Kyte, \\ Takafumi Matsui, and Morten Smelror
}

\section{Introduction}

In September 2007, thirty-three scientists attended an international workshop in Longyearbyen (Svalbard, Norway) to discuss impacts of extraterrestrial bodies into marine environment and to prepare for the drilling of the 142-Ma-old Mjølnir impact structure in the Barents Sea (Fig. 1; Gudlaugsson, 1993; Dypvik et al., 1996, Tsikalas et al., 1998). A field trip visited the ejecta layer in the Janusfjellet Mountain in Isfjorden, just outside Longyearbyen (Fig. 2).

The workshop focused on two topics: 1) mechanisms of marine impact cratering including ejecta formation and distribution, geothermal reactions, and the formation of tsunami, and 2) environmental effects of marine impacts. Both topics are highly relevant to the Mjølnir event and the geological evolution of the Arctic, as well as to the biological changes at the Jurassic-Cretaceous boundary. Against this background were a) concrete drilling targets formulated, b) plans outlined for compiling data from existing geological and geophysical surveys as the basis for Integrated Ocean Drilling Program (IODP) and International Continental Scientific Drilling Program (ICDP) drilling proposals, and c) a steering group and science teams established for compiling old and new material as a foundation for the development of drilling proposal.

\section{Scientific Background}

Asteroid and comet impacts are now recognized as an important and regular geological process releasing vast amounts of energy and resulting in near instantaneous increase in temperature and pressure, structural deformation, and redistribution of target materials. It is presently accepted that impacts, especially those in a marine environment, have very important influences on the development of the Earth. However, detailed knowledge of the geological and physical aspects of the impact process itself, as well as its environmental and biological consequences, is still limited. This is mainly due to the fact that a large majority of the $\sim 170$ currently known impact craters on the Earth and their ejecta deposits are rather poorly preserved. Only twenty-five of these craters represent marine impacts, and very few of those have remained submerged with a potential for preservation of the original structure (Dypvik and Jansa, 2003). No completely retained marine crater has been investigated in detail yet, while in the last years ICDP land coring projects in the Chicxulub, Bosumtwi, and Chesapeake Bay impact structures were of great scientific gain.

One of the best preserved known impact craters on Earth is the Mjølnir impact structure. It was discovered by seismic data during petroleum exploration in the Barents Sea but never sampled by coring. An extensive geophysical database has been collected over the Barents Sea, and more than sixty petroleum exploration wells have been drilled, particularly along basin margins and on structural highs. In addition, many shallow drill holes on sub-cropping sedimentary sequences have been drilled in the more central and remote areas of the Barents Sea. See also the Norwegian Petroleum Directorate (NPD; http://www.npd.no).

The Mjølnir Structure is $40 \mathrm{~km}$ in diameter and is located at the Bjarmeland Platform in the central Barents Sea (Fig. 1), beneath $350 \mathrm{~m}$ of water. Its elevated central high (Fig. 3) is

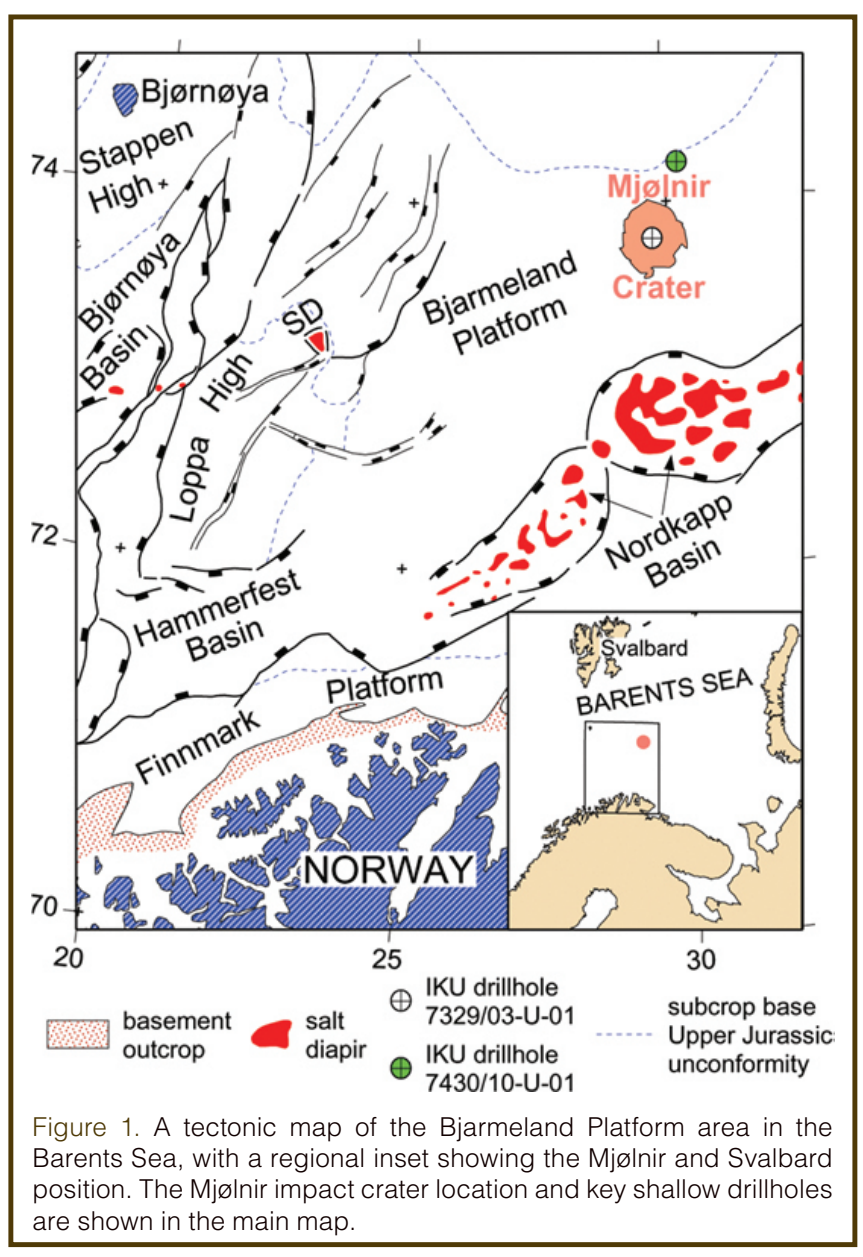


covered by $\sim 50 \mathrm{~m}$ of younger sediments. Geophysical, geological, and mineralogical data unequivocally substantiate the origin of the structure by an impact event into a sedimentary platform with 300-500 $\mathrm{m}$ paleo-water depth (e.g., Dypvik et al., 1996; Smelror et al., 2001; Sandbakken et al., 2005). The impact has been dated at about $142 \mathrm{Ma}$ (Dypvik et al., 1996), very close to the Jurassic-Cretaceous boundary. At this time, the platform comprised upper Paleozoic strata, mainly carbonates and evaporates, overlain by $4-5 \mathrm{~km}$ of thick Mesozoic siliciclastic marine sediments (Dallmann, 1999).

\section{The Workshop Program}

The workshop included the following topics:

(1) Review the science behind marine impacts and the Mjølnir project. The state of knowledge, and ongoing geological and geophysical investigations in the Arctic realm, the Barents Sea, and Mjølnir were outlined by specialists of Arctic geology and members of the Mjølnir research group.

(2) Review of petroleum exploration drilling in the Barents Sea was presented by one representative from the NPD and representatives from Norsk Hydro and Statoil (now StatoilHydro). Drilling experts from ICDP, Drilling, Observation and Sampling of the Earths Continental Crust (DOSECC) and IODP presented different drilling options.

(3) Scientific goals and drilling strategies for the Mjølnir. A plenary session was followed by discussions in two break-out groups, whose recommendations are summarized below.

(4) An excursion was organized to the site of possible Mjølnir ejecta at the mountain Janusfjellet in Isfjorden (Fig. 2).

\section{The Workshop Outcome}

Deep wells in the Mjølnir impact structure would be of great interest to the international scientific community, in order to study the shock propagation, collapse, and re-sedimentation of the $>6$-km-thick sedimentary succession. Coring through this succession will make structural analysis and detailed understanding of crater generation and deformation possible and help constrain numerical modeling. However, the costs for deep coring in the harsh environments of the Barents Sea makes it

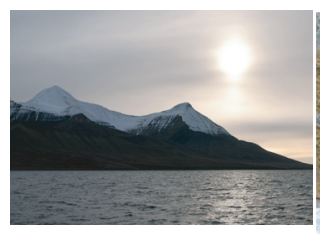

Figure 2. The sun over Isfjorden and the ejecta locality at Janusfjellet.

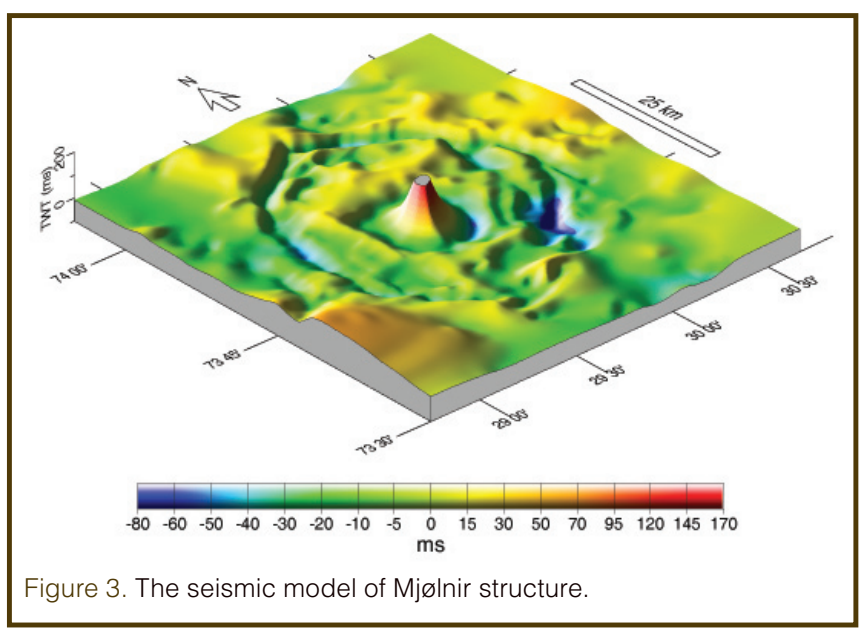

unrealistic to raise funding for such operations in the foreseeable future.

One of the great scientific advantages with the Mjølnir impact crater is the clear correlation between the crater and its very well preserved ejecta found in shallow drillings in the Barents Sea and on land (Svalbard and possibly Siberia; Dypvik et al., 2004; 2006). During a large part of late Jurassic and early Cretaceous, the Barents Sea region formed an epicontinental sea dominated by anoxic sedimentation of black, organic-rich clays. The Mjølnir bolide impacted into these sediments, and the crater and portions of the ejecta localities were buried and have remained buried under sediments and water since its formation. Those ejecta localities are well-preserved and accessible by shallow drilling (e.g., Bugge et al., 2002). It is one of the few places on the Earth where such important relations can be studied in detail. This is clearly of great importance for understanding the crater and ejecta formation, including the study the environmental consequences of marine impacts (Dypvik et al., 2006; Smelror et al., 2002). We will use Mjølnir as a type locality to study ejecta generation and distribution and possible relationships between the impact and biotic evolution. Mjølnir ejecta may even serve as a Boreal-Tethyan stratigraphic marker and could be useful in correlation of these two distinct provinces near the poorly understood Jurassic-Cretaceous boundary (Smelror et al., 2001; 2002). Further research could greatly expand our initial knowledge on tsunami generation and formation, impact ignitions of hydrocarbons in the target area, fires and subsequent soot precipitation. Calculations show that organic matter equivalent to a year's oil production of one Norwegian Shelf giant field (about thirty million std. $\mathrm{m}^{3}$ oil in place) was burned during the first twenty minutes of the Mjølnir event (Dypvik et al., 2008).

The development of the Mjølnir research program should be carried out in full cooperation with the NPD and in close contact with the oil industry active in the region (e.g., StatoilHydro, ENI), making use of their extensive geophysical database and deep wells. A two-step drilling project was recommended: 
Step 1. Drilling of five to six, up to 300-m-deep core holes in 350-400 $\mathrm{m}$ water depth around the Mjølnir structure to map and understand ejecta formation and distribution, coupled with in situ disturbance of sediments due to seismic and shock waves, or erosion by displaced water near the crater. Analysis of the cored material will be accompanied by sophisticated simulation models (Shuvalov and Dypvik, 2004) of the formation and deposition of ejecta in a marine environment.

Step 2. Drilling of one or two deep holes within the central moat to understand the inner structure of a large crater. At this point, however, the cost of such a project possibly requiring riser drilling is difficult to assess.

\section{Future Plans}

An international steering group (the authors of this paper) was established and charged with producing a draft project proposed by the end of 2008 . The steering group will also be responsible for compiling the final drilling proposals to IODP, ICDP, and the Norwegian Research Council (NFR) by spring 2009. For further information on the Mjølnir drilling project, please contact the authors or visit http://mjoelnir. icdp-online.org/.

\section{Acknowledgements}

The workshop was kindly supported by ICDP, ESF-The Magellan Program, Statoil, Norsk Hydro, University Center on Svalbard, and University of Oslo.

\section{References}

Bugge, T., Elvebakk, G., Fanavoll, S., Mangerud, G., Smelror, M., Weiss, H.M., Gjelberg, J., Kristensen, S.E., and Nilsen, K., 2002. Shallow stratigraphic drilling applied in hydrocarbon exploration of the Nordkapp Basin, Barents Sea. Mar. Pet. Geol., 19:13-37, doi: 10.1016/S0264-8172(01)00051-4.

Dallmann, W.K., 1999. Lithostratigraphic Lexicon of Svalbard. Tromsø, Norway (Norwegian Polar Institute), $318 \mathrm{pp.}$

Dypvik, H. and Jansa, L., 2003. Sedimentary signatures and processes during marine bolide impacts: a review. Sed. Geol., 161:309-337, doi: 10.1016/S0037-0738(03)00135-0.

Dypvik, H., Gudlaugsson, S.T., Tsikalas, F., Attrep, M., Jr., Ferrell, R.E., Jr, Krinsley, D.H., Mørk, A., Faleide, J.-I., and Nagy, J., 1996. The Mjølnir structure - An impact crater in the Barents Sea. Geology, 24:779-782, doi:10.1130/00917613(1996) 024<0779:MLSAIC >2.3.CO;2.

Dypvik, H., Smelror, M., Sandbakken, P.T., Salvigsen, O.T., and Kalleson, E., 2006. Traces of the marine Mjølnir impact event. Palaeogeogr. Palaeoclimatol. Palaeoecol., 241: 621-634.

Dypvik, H., Mørk, A., Smelror, M., Sandbakken, P.T., Tsikalas, F., Vigran, J.O., Bremer, G.M.A., Nagy, J., Gabrielsen, R.H., Faleide, J.I., Bahiru, G.M., and Weiss, H.M., 2004. Impact breccia and ejecta from the Mjølnir crater in the Barents Sea-The Ragnarok Formation and Sindre Bed. Nor. J. Geol., 84 (3), 143-167.
Dypvik, H., Wolbach, W., Shuvalov, V., and Weaver, S., 2008. Did the Mjølnir asteroid impact ignite Barents Sea hydrocarbon source rocks? In Evans, K., Horton, J.W., Jr., King, D.T., Jr., and Morrow, J.R. (Eds.) The Sedimentary Record of Meteorite Impacts: Geological Society of America Special Paper, 437: 65-72, Boulder, Colo. (Geological Society of America)

Gudlaugsson, S.T., 1993. Large impact crater in the Barents Sea. Geology, 21:291-294, doi:10.1130/0091-7613(1993)021<0291: LICITB>2.3.CO;2.

Sandbakken, P.T., Lagenhorst, F., and Dypvik, H., 2005. Shock metamorphism of quartz at the submarine Mjølnir impact crater, Barents Sea. Meteor. Planet. Sci., 40:1363-1375.

Shuvalov, V. and Dypvik, H., 2004. Ejecta formation and crater development of the Mjølnir impact. Met. Planet. Sci., 39(3):467-478.

Smelror, M., Dypvik, H., and Mørk, A., 2002. Phytoplankton blooms in the Jurassic-Cretaceous boundary beds of the Barents Sea possibly induced by the Mjølnir impact. In Buffetaut, E., and Koeberl, C. (Eds.), Geological and Biological Effects of Impact Events. Impact Studies, vol. 1, Heidelberg, (Springer), 69-81.

Smelror, M., Kelley, S., Dypvik, H., Mørk, A., Nagy, J., and Tsikalas, F., 2001. Mjølnir (Barents Sea) meteorite impact ejecta offers a Boreal Jurassic-Cretaceous boundary marker. Newsletters in Stratigraphy, 38:129-140.

Tsikalas, F., Gudlaugsson, S.T., and Faleide, J.-I., 1998. The anatomy of a buried complex impact structure: the Mjølnir Structure, Barents Sea. J. Geophys. Res., 103:30469-30483.

\section{Authors}

Philippe Claeys, Department of Geology, Vrije Universiteit Brussel, Pleinlaan 2, B-1050 Brussels, Belgium, e-mail: phclaeys@vub.ac.be.

Alex Deutsch, Institut für Planetologie, Westfaelische Wilhelms-Universität Münster Wilhelm-Klemm-Str. 10, D48149 Münster, Germany.

Henning Dypvik (coordinator), Department of Geosciences, University of Oslo, P.O. Box 1047, No 0316 Oslo, Norway.

Frank T. Kyte, Institute of Geophysics and Planetary Physics, UCLA University of California, Los Angeles, Calif. 90095-1567, U.S.A.

Takafumi Matsui Department of Complexity Science and Engineering, University of Tokyo, Tokyo, Japan.

Morten Smelror, Geological Survey of Norway, No 7491 Trondheim, Norway.

\section{Related Web Links}

http://mjoelnir.icdp-online.org/

http://www.npd.no

\section{Photo Credits}

Figs. 1 and 3: Filippos Tsikalas, University of Oslo and ENI, Norway

Fig. 2: P. Claeys, A. Deutsch. 